\title{
Upaya Mengelola Kepuasan Nasabah Melalui Dimensi Kualitas Pelayanan (Studi Kasus Pada Nasabah Bank Tabungan Negara Cabang Pekanbaru)
}

\author{
ZULIA KHAIRANI \\ Universitas Lancang Kuning Jln Yos Sudarso KM 8 Rumbai, \\ Pekanbaru, Telp (0761) 52581 Fax (0761) 52581
}

\begin{abstract}
Service quality is very important in the banking business. In addition to offering a wide range of products, improvements in terms of information technology, physical services, and non-physical services intended to improve the quality of service. To measure the level of satisfaction is necessary to know the extent to which the quality of services provided are able to create customer satisfaction. This study aims to analized how much influence the quality of service to customer satisfaction BTN Bank Branch Pekanbaru. After learning literature review, an understanding of the influence of the physical form (tangibles), reliability (reliability), assurance (assurance), responsiveness (responsiveness), and awareness (empathy) with the variables that influence can be seen as a base strategy for development customer satisfaction.The sample in this study was 100 customers of Bank BTN Pekanbaru randomized using a sampling technique accidental sampling.Statistical analysis showed that the tangibles, reliability, responsiveness, and empathy partially and simultaneously positive and significant impact on customer satisfaction Bank BTN Pekanbaru.
\end{abstract}

Keywords: Customer Satisfaction, Tangible, Reliability, Responsiveness, Assurance, and Empathy

Dalam dunia modernperanan perbankan dalam memajukan perekonomian suatu negara sangatlah besar.Lembaga perbankan merupakan inti dari sistem keuangan suatu negara (Hermansyah, 2009:7). Hampir semua sektor yang berhubungan dengan kegiatan keuangan selalu membutuhkan jasa bank (Kasmir, 2009:2). Kualitas pelayanan sangat penting dalam bisnis perbankan.Selain menawarkan berbagai macam produk, perbaikan di sisi teknologi informasi, pelayanan fisik,danpelayanan non fisikdimaksudkan untuk meningkatkan kualitas pelayanan (Ariyani, 2008).

Penilaian nasabah terhadap suatu bank dipengaruhi oleh bagaimana nasabah tersebut memaknai produk bank atau pelayanan yang diterima. Menurut Bedi (2010) memberikan layanan yang berkualitas tinggi adalah suatu keharusan untuk mencapai kepuasan pelanggan.Bagi pelanggan, kualitas pelayanan dan kepuasan pelanggan berasal dari layanan yang terorganisir.Secara sederhana kinerja keuangan sesungguhnya bersumber pada kesetiaan pelanggan. Pelanggan yang setia dapat menghemat biaya hingga empat sampai lima kali dibandingkan biaya yang dikeluarkan untuk mendapatkan pelanggan baru. Kenyataan ini menjadi tantangan tersendiri bagi dunia perbankan, yaitu bagaimana menciptakan keinginan pelanggan untukmenggunakan produk dan jasa perusahaan serta menjalin hubungan yang dekat dengan nasabahnya (Suhardi, 2006).

Penilaian pelanggan perlu melakukan perbaikan mendasar dalam sikap dan perilaku, karena kepuasan pelanggan ini sangat subjektif penilaiannya sehingga perlu perbaikan secara subjektif pula dan bentuk emosional petugas dalam memberikan pelayanan dengan penuh perhatian yang lebih. (B. Suroto, 2015)

Penciptaan nilai yang superior akan menghasilkan tingkat kepuasan yang merupakan tingkat perasaan dimana 
sseorang menyatakan hasil perbandingan atas kinerja produk/jasa yang diterima dan yang diharapkan (Kottler, 2014). Untuk mengukur tingkat kepuasan sangatlah perlu mengetahui sejauh mana kualitas pelayanan yang diberikan mampu menciptakan kepuasan bagi pelanggan.Menurut Tantri (2012:38) mengatakan kepuasan adalah tingkat perasaan seseorang setelah membandingkan kinerja produk (hasil) yang ia rasakan dengan harapannya. Jadi tingkat kepuasan merupakan fungsi dari perbedaan antara kinerja yang dirasakan dan harapannya.Pelanggan bisa mengalami salah satu dari tiga tingkat kepuasan yang umum. Jika kinerja dibawah harapan, pelanggan akan puas. Apabila kinerja melampaui harapan, pelanggan akan sangat puas, senang, atau bahagia.

Penelitian ini dirancang untuk menguji tingkat pelayanan terhadap kepuasan nasabah dan untuk mengetahui apakah kualitas pelayanan berupa wujud fisik (tangibles), kehandalan (reliability), daya tanggap (responsiveness), jaminan (assurance) dan kepedulian (emphaty) berpengaruh pada kepuasan nasabah. Dalam industri jasa, pelanggan pasti berharap untuk mendapatkan pelayanan yang baik, sementara itu di pihak lain pemberi jasa juga mempunyai standar kualitas dalam memberikan jasanya. Demikian juga dalam dunia perbankan yang merupakan insdustri jasa, nasabah sebagai pelanggan pasti mempunyai harapan terhadap kualitas jasa tertentu yang mungkin berbeda dengan pemberi pelayanan. Persepsi konsumen terhadap kualitas pelayanan itu sendiri merupakan penilaian menyeluruh konsumen atas keunggulan suatu pelayanan (Kotler, 2007).

Menurut Tciptono (2005), kualitas merupakan kondisi dinamis yang berhubungan dengan produk, jasa, manusia, proses dan lingkungan yang memenuhi atau melebihi harapan. Sehingga definisi kualitas pelayanan dapat diartikan sebagai upaya pemenuhan kebutuhan dan keinginan konsumen serta ketepatan penyampainnya dalam mengimbangi harapan konsumen.
Pelayanan yang berkualitas menurut Valerie A. Zeithami (dalam Rajawali View, 2003) adalah kemampuan suatu perusahaan menyajikan atau memenuhi apa yang dijanjikannya kepada pelanggan.Kotler (2007) menyatakan bahwa kepuasan adalah perasaan senang atau kecewa seseorang yang berasal dari perbandingan kesannya terhadap kinerja atau hasil suatu produk dan harapanharapannya. Jika kinerja berada dibawah harapan, pelanggan tidak puas. Hal ini dapat membawa dampak negatif bagi perusahaan yaitu dapat menurunkan jumlah pelanggan dan menyebabkan pelanggan tidak tertarik lagi menggunakan jasa perbankan.

Adapun faktor-faktor yang berpengaruh terhadap kepuasan pelangganadalah, pertamawujud fisik (Tangible), dimana Berwujud diartikan debagai tampilan fisik. Biasanya digunakan perusahaan untuk menaikkan image di mata konsumen yang dapat digambarkan dengan kebersihan ruangan, kerapian berpakaian, dan penataan tempat. Kedua, keandalan adalah kemampuan untuk memberikan jasa sesuai dengan yang dijanjikan dengan akurat dan handal. Ini berkaitan dengan kemampuan menyediakan pelayanan dengan sikap simpatik, ketepatan waktu pelayanan, profesional dalam melayani nasabah, dan sistem pencatatan yang akurat.

Ketiga, Daya tanggap adalah kesedian untuk membantu pelanggan dan memberikan dengan segera dan tepat.Ini menekankan pada perhatian dan kecepatan dalam menghadapi permintaan, pernyataan, keluhan serta kesulitan pelanggan.Keempat, jaminan (assurance) mencakup pengetahuan, kemampuan, kesopanan, sifat dapat dipercaya yang dimiliki para staf, dan bebas dari bahaya, risiko atau keragu-raguan.Kelima, empati (empathy) adalah perhatian secara individu yang diberikan oleh penyedia jasa sehingga pelanggan merasa penting, dihargai dan dimengerti oleh perusahaan. Ini adalah bagaimana perusahaan menyakinkan pelanggannya bahwa mereka itu adalah unik dan istimewa dan dapat digambarkan dengan perhatian secara personal kebutuhan umumnya 
nasabah ingin diperlakukan dan diperhatikan secara khusus oleh pihak pengelola bank.

Penelitian Martiawati (2009) yang berjudul, "Analisis Pengaruh Brand Image, Kualitas pelayanan dan Fasilitas SPBU "Pasti Pas" Terhadap Kepuasan Konsumen Pengguna Kendaraan Bermotor". Dalam penelitian ini, sampel yang diambil adalah 100 orang, dengan menggunakan teknik purposive sampling. Hasil dari pengujian hipotesis secara parsial, ketiga variabel berpengaruh secara signifikan terhadap kepuasan konsumen. Faktor yang paling berpengaruh terhadap kepuasan konsumen adalah kualitas pelayanan.

Penelitian yang dilakukan Dodik Agung (2004) yaitu, Pengaruh Kualitas Pelayanan Terhadap Kepuasan Nasabah Kredit Perorangan dan Kelompok: Studi Kasus pada BPR Bank Pasar Kabupaten Karanganyar. Menggunakan dimensidimensi kualitas pelayanan yang dikembangkan oleh Parasuraman et al (1998) yang menyatakan variabel bebas reliability, responsiveness, emphaty, assurance, dan tangible secara individual maupun secara bersama-sama berpengaruh signifikan terhadap kepuasan nasabah dan membuktikan bahwa variabel responsiveness merupakan variabel bebas yang paling dominan pengaruhnya.

Penelitian yang dilakukan Hartanto (2010), yaitu analisis pengaruh kualitas Layanan Jasa Perbankan Terhadap Kepuasan Nasabah PD BPR Bank Jogja. Penelitian ini menguji pengaruh 5 dimensi kualitas pelayanan yaitu reliability, responsiveness, emphaty, assurance, dan tangibleterhadap kepuasan nasabah. Hasil Penelitian menunjukkan variabel empati memiliki pengaruh yang positif dan signifikan terhadap kepuasan nasabah, sedangkan variabel lainnya memiliki pengaruh yang positif tetapi tidak signifikan pengaruhnya terhadap kepuasan nasabah. Berdasarkan hal tersebut, dapat ditarik hipotesis sebagai berikut, H1 :Tangiblesecara parsial berpengaruh positif dan signifikan terhadap kepuasan nasabah, $\mathrm{H}_{2}$ :Reliability secara parsial berpengaruh positif dan signifikan terhadap kepuasan nasabah, $\mathrm{H}_{3}$ : Responsivenesssecara parsialberpengaruh positif dan signifikanterhadap kepuasan nasabah, $\mathrm{H}_{4}$ :Assurance secara parsialberpengaruh positif dan signifikan terhadap kepuasan nasabah. $\mathrm{H}_{5}$ :Emphatysecara parsial berpengaruh positif dan signifikan terhadap kepuasan nasabah, $\mathrm{H}_{6}$ : Tangible, Reliability, Responsiveness, Assurance, Empaty secara simultan berpengaruh positif dan signifikan terhadap kepuasan nasabah.

\section{METODE}

Populasi dalam penelitian ini adalah nasabah Bank BTN Cabang Pekanbaru. Jumlah sampel diambil sebanyak 100 responden.Metode pengumpulan data yang digunakan dalam penelitian ini adalah metode survei yang menggunakan daftar pertanyaan (kuesioner) yang disampaikan langsung kepada responden yaitu nasabah Bank BTN cabang Pekanbaru. Dari jawaban daftar pertanyaan yang diajukan pada responden diolah dengan skala likert. Definisi operasional merupakan penjabaran akan definisi variabel dan indikator pada penelitian ini.

Tahapan-tahapan yang digunakan untuk menganilisis data yaitu: Uji Validitas, uji Reliabilitas, Uji Penyimpangan Asumsi Klasi, Uji Normalitas Uji Multikolinearitas, Uji Heteroskedastisitas, Analisis Regresi Berganda, dimana persamaan regresi berganda yang dipergunakan adalah sebagai berikut, $\mathrm{Y}=\alpha$ $+\beta_{1} X_{1}+\beta_{2} X_{2}+\beta_{3} X_{3}+\beta_{4} X_{4}+\beta_{5} X_{5}+$ e. Selanjutnya dilakukan Uji koefisien determinasi $\left(\boldsymbol{K}^{\mathbf{2}}\right)$, dan pengujian hipotesis dengan Uji $F$ (secara simultan) dan $\mathrm{Uji}-\mathrm{t}$ (secara parsial)

\section{HASIL}

Berdasarkan tabel 4 dibawah, maka persamaan regresi linier berganda yang dihasilkan adalah sebagai berikut :

$Y=3,190+0,366 X_{1}+0,185 X_{2}+0,455 X_{3}$ $+0,201 X_{4}+0,209 X_{5}$

Dalam penelitian ini dapat dilihat bahwa variabel yang memiliki pengaruh paling besar adalah daya tanggap total dengan standardized coefficents yaitu 0,580.

Pada pengujian secara simultan (Uji F) diperoleh $F$ hitung sebesar 66,675 
dengan signifikansi sebesar 0,000. Diperoleh $\mathrm{F}$ tabel sebesar 4,40. Dengan demikian dapat diketahui $\mathrm{F}$ hitung $>\mathrm{F}$ tabel dengan signifikansi $(0,000<0,05)$, artinya variabel tangible, reliability, responsiveness, assurance, dan empathy secara bersamasama berpengaruh signifikan terhadap variabel kepuasan nasabah.

Pada pengujian secara parsialdiperoleh nilai $t$ hitung seluruh variabel independent lebih besar dari nilai $\mathrm{t}$ tabel $=$ 1,98. sehingga $\mathrm{H}_{0}$ ditolak dan $\mathrm{H}_{1}, \mathrm{H}_{2}, \mathrm{H}_{3}, \mathrm{H}_{4}$, $\mathrm{H}_{5}$ diterima atau dapat disimpulkan bahwa secara parsial Tangible, Reliability, Responsiveness, Assurance, dan Empathy berpengaruh positif dan signifikan terhadap kepuasan nasabah.

Dari hasil SPSS diperoleh besarnya nilai $\mathrm{R}$ diperoleh 0,754 sehingga diketahui nilai koefisien determinasi simultan $\left(\mathrm{R}^{2}\right)$ sebesar 0,627 hal ini dapat diartikan bahwa variabel Tangible (X1), reliability (X2), responsiveness (X3), Assurance (X4), Empathy (X5) mampu menjelaskan sebesar $62,7 \%$ terhadap kepuasan nasabah (Y). Sedangkan sisanya 37,3\% dijelaskan faktorfaktor lain yang tidak termasuk pada penelitian ini.

\section{PEMBAHASAN}

Hasil penelitian menunjukkan
tangible, assurance, dan empathy secara parsial masing-masing memiliki pengaruh positif dan signifikan terhadap kepuasan nasabah bank BTN cabang Pekanbaru. Hasil penelitian ini mendukung hasil penelitian sebelumnya yang dilakukan Dodik Agung (2004) yaitu, Pengaruh Kualitas Pelayanan Terhadap Kepuasan Nasabah Kredit Perorangan dan Kelompok: Studi Kasus pada BPR Bank Pasar Kabupaten Karanganyar. Menggunakan dimensi-dimensi kualitas pelayanan yang dikembangkan oleh Parasuraman et al (1998) yang menyatakan variabel tangible, reliability, responsiveness, assurance, dan empathy secara individual maupun secara bersama-sama berpengaruh signifikan terhadap kepuasan nasabah.

Hasil penelitian ini mendukung hasil penelitian sebelumnya yang dilakukan Suhendra dkk (2010), yaitu Analisis Pengaruh Kualitas Pelayanan terhadap Kepuasan Nasabah Kredit pada BPR Arthaguna sejahtera, dimana keandalan (Reliability) berpengaruh positif dan signifikan terhadap kepuasan nasabah.Hasil penelitian ini juga mendukung hasil penelitian sebelumnya yang dilakukan Hartanto (2010), yaitu Analisis Pengaruh Kualitas Pelayanan Jasa Perbankan terhadap Kepuasan Nasabah pada PD. BPR Bank Jogja, dimana hasil pengujian membuktikan bahwa variabel Empati secara parsial memiliki pengaruh yang positif dan signifikan terhadap Kepuasan Nasabah.

Hasil Penelitian ini juga mendukung penelitian sebelumnya yang dilakukan oleh Dabholkar, et al. (2000) menyatakan bahwa kualitas jasa mempunyai pengaruh yang signifikan terhadap kepuasan pelanggan.Pelayanan yang berkualitas menurut Valerie A. Zeithami (dalam Rajawali View, 2003) adalah kemampuan suatu perusahaan menyajikan atau memenuhi apa yang dijanjikannya kepada pelanggan.

\section{SIMPULAN}

Penelitian ini dilakukan di Bank BTN cabang Pekanbaru.Responden adalah nasabah Bank BTN cabang Pekanbaru.Hasil penelitian ditemukan bahwa 5 dimensi kualitas pelayanan yaitu Tangible, Reliability, Responsiveness, Assurance, dan empathysecara simultan dan parsial berpengaruh positif dan signifikan terhadap kepuasan nasabah Bank BTN cabang Pekanbaru. dari hasil penelitian terungkap bahwa responsiveness paling berpengaruh terhaadap kepuasan nasabah bank BTN cabang Pekanbaru.

\section{DAFTAR RUJUKAN}

Agustiyadi, T. 2008. Pentingnya Mengenali Tipe-tipe Loyalitas Nasabah Untuk Meningkatkan Profit. (online), (triagus.multiply.com/reviews/item ) 
Akbar, M.M., and Parvez, N. 2009. Impact of Services Quality, Trust, andCustomer Satisfaction on Customer Loyalty, ABAC Journal, Vol. 29, No. 1,pp. 24-38.

Al-Rousan, Ramzi, M., and Mohamed, B. 2010. Customer Loyalty and theImpacts of Service Quality: The Case of Five Star Hotels in Jordan International, Journal of Business and Economic Sciences, Vol. 5, pp. 202-208.

Alma, Buchari. 2005. Manajemen Pemasaran dan Pemasaran Jasa. Bandung: Alfabeta

Anggraeni, Savitri. 2012. Pengaruh E-Service Quality terhadap Kepuasan dan Loyalitas Pelanggan (Kasus Pada Pengguna Internet Banking diCommonwealth Bank Cabang Seminyak Bali), Tesis, Program Studi Magister Manajemen Universitas Udayana, Denpasar.

Ariyani, F. 2008. Membangun Loyalitas Nasabah Melalui Peningkatan KualitasPelayanan dan Keunggulan Produk (Studi Empiris Pada PT. Bank BukopinTbk di Kota Semarang), Tesis, Magister Manajemen UniversitasDiponegoro, Semarang.

B. Suroto (2015) 'Studi Kepuasan Pelanggan Peserta Jaminan Kesehatan Pada RSUD Arifin Achmad Pekanbaru'. jurnal daya saing.

Bloemer J, Ko de Ruyter dan Matin Wetzels. 1998. Lingking Perceived Service Quslity and Service Loyalty: A Multi Dimensional Perspective, EuropeanJournal of Marketing, Vol. 33, pp. 11-12.

Bowen, John T \& Shiang-Lih Chen.2001. The Relationship Between Customer Loyalty and Customer Satisfaction, International Journal of ContemporaryHospitality
Management, Vol. 13, No. 5, pp. 213-217.

Caruana, A. 2002. Service Loyalty: The Effects of Service Quality and The Mediating Role of Customer Satisfaction, European Journal of Marketing, Vol. 36, No. 7-8, pp. 811-828.

Choudhury, K. 2008. Service Quality: Insights from The Indian Banking Scenario, Australasian Marketing Journal, Vol. 16, No. 1, pp. 48-61.

Cronin, J. Joseph Jr, Michael K. Brady dan G. Tomas M. Hult. 2000.Assessing The Effects of Quality, Value, and Customer Satisfaction on ConsumerBehavioral Intentions in Service Environments, Journal of Retailing, Vol.76, No. 2, pp. 193218.

Edgar, M dan Galia, F. 2009. Why and How Service Quality Perceptions Impact Consumer Responses, Journal of Managing Service Quality, Vol. 19, No. 4 pp. 474485.

Ghozali, Imam, 2011, Aplikasi Analisis Multivariasi Dengan Program SPSS, Semarang. BP Universitas Diponegoro.

Hartanto, Tri, 2010, Analisis Pengaruh Kualitas Pelayanan Terhadap Kepuasan Nasabah (Studi Kasus PD BPR Jogja), papers.gunadarma.ac.id

Kasmir. 2007. Bank dan Lembaga Keuangan Lainnya. Edisi 6. Jakarta: PT.RajaGrafindo Persada.

Kotler, P. dan Keller, K.L. 2007. Manajemen Pemasaran. Jilid 1 dan 2. Jakarta:PT Indeks. 